\title{
Comparison of the chemical composition and the particle size of alimentary bolus in goats and sheep fed various diets
}

\author{
C Masson, F Faurie, F Arista, JL Tisserand \\ Laboratoire de Recherches INRA de la Chaire de Zootechnie, \\ 26, bd Dr-Petitjean, 21000 Dijon, France
}

Introduction - Among the different factors accounting for the better utilization of poor forages by goats, compared with sheep, urea recycling and better mastication during ingestion have been reported (Masson et al, 1986; Morand-Fehr et al, 1987). Our purpose was to measure the particle size in the alimentary bolus and to indirectly assess urea recycling, by chemical analysis of alimentary bolus.

Materials and Methods - The chemical composition and the particle size of the offered forage and the alimentary bolus were measured on 3 wether goats and 3 sheep fitted with an esophagus cannula, for 3 wk after a $15 \mathrm{~d}$ preexperimental period. Two forages were studied successively: orchard-lucerne hay and wheat straw (diet 1: $800 \mathrm{~g}$ lucerne $+200 \mathrm{~g}$ maize; diet 2: $1000 \mathrm{~g}$ wheat straw $+135 \mathrm{~g}$ soya bean cake $+150 \mathrm{~g}$ maize). For the measurements, the animals, fed at maintenance level, received a forage meal during a $30 \mathrm{~min}$ period. Water was removed just before this meal.

Results et Discussion - Regardless of the animal species, the straw diet alimen- tary bolus had a greater $(P<0.05) \mathrm{dry}$ matter content than the lucerne alimentary bolus (table 1). With the lucerne hay, the crude protein (CP) and ash contents were the same $(P<0.05)$ for the offered hay and the alimentary bolus of both species. On the other hand, when goats and sheep ate straw, the $\mathrm{CP}$ and ash contents were greater $(P<0.05)$ for the alimentary bolus than for the straw. The mean particle size of the esophagus bolus was the same $(P<0.05)$ for both, regardless of the diet.

In fact it seems that diet quality can change saliva composition and especially its CP content. Other measurements of saliva urea content are needed to verify this hypothesis of better urea recycling.

Masson C, Alrahmoun W, Tisserand JL (1986) Ann Zootech 35, 49-60

Morand-Fehr P, Giger S, Sauvant D, Broqua B, de Simiane $M$ (1987) In: Les Fourrages Secs, Récolte, Traitement, Utilisation. INRA, Versailles, 391-422

Table I. Chemical composition and particle size of offered forage and alimentary bolus.

\begin{tabular}{lrrrrrr}
\hline & \multicolumn{3}{c}{ Goats } & & \multicolumn{2}{c}{ Sheep } \\
\cline { 2 - 3 } \cline { 6 - 7 } \cline { 5 - 7 } & \multicolumn{2}{c}{ lucerne } & straw & & lucerne & straw \\
\hline Feed DM content & $89.8 \pm 2.3$ & $93.8 \pm 1.8$ & & $90.8 \pm 2.1$ & $92.2 \pm 1.8$ \\
Bolus DM content & $20.1 \pm 2.6$ & $33.7 \pm 5.6$ & & $17.5 \pm 2.3$ & $33.4 \pm 4.2$ \\
Feed ash content & $9.3 \pm 0.8$ & $8.9 \pm 1.4$ & & $8.9 \pm 1.2$ & $9.2 \pm 1.2$ \\
Bolus ash content & $10.7 \pm 2.3$ & $13.6 \pm 1.8$ & & $12.0 \pm 4.1$ & $14.9 \pm 1.7$ \\
Feed CP content & $15.8 \pm 1.4$ & $3.1 \pm 0.8$ & & $16.2 \pm 1.2$ & $3.4 \pm 0.7$ \\
Bolus CP content & $15.8 \pm 2.1$ & $9.5 \pm 4.6$ & & $16.8 \pm 1.3$ & $12.3 \pm 5.6$ \\
Feed particle size (mm) & $1.73 \pm 0.18$ & $2.05 \pm 0.10$ & & $1.75 \pm 0.16$ & $1.98 \pm 0.15$ \\
Bolus particle size (mm) & $1.05 \pm 0.18$ & $0.81 \pm 0.09$ & & $1.21 \pm 0.27$ & $0.85 \pm 0.09$ \\
\hline
\end{tabular}

